\title{
O Leitmotiv Fortuny e Odette Espaço e tempo na tessitura de Proust
}

\author{
Bernardete Oliveira Marantes ${ }^{1}$
}

\begin{abstract}
RESUMO: A moda das roupas está plenamente integrada ao todo da obra de Proust e é por essa razão que nos debruçamos sobre dois temas concernentes às roupas: o leitmotiv Fortuny e a personagem Odette. O motivo Fortuny mereceu de Proust uma atenção delicada, pois, emaranhado ao seu tecido literário, o desenvolvimento do tema manifesta uma minuciosa construção estética tramada por diferentes fios que encontrarão, em seu término, a roupa e o tecido de Fortuny em consonância com a arte e as cidades, entidades refletidoras sobretudo do espaço afetivo tramado na tessitura proustiana. Em posição distinta, mas complementando o tecido literário, surge a personagem atemporal Odette, que não participa do leitmotiv; Odette, que, sem seguir uma moda, tem estilo, soube como poucas mulheres construir, por meio de sua representação indumentária sua própria identidade e alteridade, ou em outros termos, ser e estar no tempo.
\end{abstract}

PALAVRAS-CHAVE: Proust; moda das roupas; leitmotiv Fortuny; Odette; espaço; tempo

\section{The Fortuny Leitmotif and Odette Space and time on Proust texture}

\begin{abstract}
The fashion of clothing is entirely connected into all Proust's work and it is for this reason that we look at this two issues concerning the clothes: the Fortuny Leitmotif and the character Odette. Proust gave a very special attention to the Fortuny Leitmotif for the theme development evidences a detailed aesthetic architecture, which threads will find in their end clothes and the Fortuny tissue in consonance with art and cities, both reflecting entities of the affective space built by Proust's texture. Concerning a distinct issue, although in a complementary literary thread, Odette, who does not participate of the leitmotif itself, emerges as an eternal character. The reason is that Odette has style and even though she does not follow fashion trends, she is one of the rare women who know how to build her own identity and otherness through her clothing representation. In other words, being for real on her time.
\end{abstract}

KEYWORDS: Proust; fashion clothing; Fortuny leitmotif; Odette; space; time

Doutora em Filosofia pela USP. Pesquisadora da obra de Marcel Proust, trabalhou sobre a arte musical à luz da filosofia de Henri Bergson no mestrado, e a moda das roupas e a correspondência entre as artes à luz da filosofia de Gilles Deleuze no doutorado. Email: <bernardetemarantes@hotmail.com>. 


\section{Introdução}

Eu construiria meu livro, não ouso dizer ambiciosamente como uma catedral, mas modestamente como um vestido

(PROUST, 1995b, p.280/ RTP IV, p.610)

É essa ambição que Proust nos revela sobre seu construto literário: ele se pretende universal, e na mesma medida monumental e quase habitual - como uma catedral e como um vestido, respectivamente. A partir de associações diversas, uma rede de correspondências se tece revelando-nos o romance, e dentro dele, uma estética afinada a um mosaico; a referência a Baudelaire (IV. Correspondances, in: Spleen et Idéal) não é gratuita, pois é ele quem permite tecer relações entre os eventos "em meio a um bosque de segredos" (des forêts de symboles), tanto nos diferentes registros sensoriais, quanto na manifestação de suas significações. Seguindo tal pretensão, a obra funda-se nas convergências, nos diálogos; ela é um bricabraque do fim de século, como sintetizou Compagnon (1989); acompanhando esse anseio sintético, para Poulet, Proust inventou "um método cuja finalidade única era de estabelecer aproximações por toda a parte" (POULET, 1992, p. 76) e, arrematando, Chevrier afirma que o autor da Recherche "faz do insignificante o reservatório inesgotável e a base de toda a significação, comunicando o infinitamente grande e o infinitamente pequeno" (CHEVRIER, 2009, p. 28). Dentro da abundância de elementos elencados e associados há o desfile das distintas modas que a Recherche promove: há a moda moveleira; a gastronômica; os artistas e as artes do momento; os lugares mais frequentados; as novidades surgidas nos salões; a moda das roupas e dos ornamentos e acessórios; as tendências exóticas oriundas do Oriente, que abrangem o árabe e o "japonismo".

Assim, e tecendo uma analogia com uma dessas modas elencadas - a moda das roupas -, pode-se dizer que, em sua gênese, a composição literária de Proust é urdida, alinhavada, costurada e isso não somente em sentido metafórico, mas também em sentido concreto, já que ele construiu seu romance escrevendo, rasurando, reescrevendo, alterando, juntando partes, e colando pedaços dispersos. Em uma passagem, já no final de sua costura literária, o narrador, contando com o auxílio de Françoise, a leal servidora que aqui toma ares de alfaiate, expõe a aproximação entre os dois tecidos, o literário e o confeccionado com fios:

[Françoise] Apontando para meus cadernos, roídos como madeira por cupim, lamentava: "Está tudo bichado, que pena, este canto de página é uma renda" examinava-o como um alfaiate. - Acho que não poderei consertar, está perdido. Como se diz em Combray, ninguém conhece as peles tão bem como as traças. Estragam sempre as melhores fazendas (PROUST, 1995b, p.281/ RTP IV, p.611). 
No cotejamento dos dois objetos, o literário e o tramado por fios, insinua-se a semelhança radical: texto, tecido, tessitura, contexto. Ambos os tecidos (o literário e o confeccionado com fios) estão em perpétuo diálogo na obra proustiana; eles se misturam na trama estética do romance revelando as cores e os signos, ora dramáticos, ora triviais, de ambas as composições. Nessa dupla chave de registro têxtil, estão fusionados os elementos tempo e espaço, que por sua vez singularizam-se, e isso em decorrência do próprio regime axiológico que os funda.

Tomando, então, tempo e espaço como elementos basilares, e aplicando-os em proveito dos dois objetos - da matéria tecido, constituída por fios, e do tecido literário, constituída por palavras -, acomodam-se dentro da obra literária proustiana duas vias díspares, mas complementares; uma que privilegia o espaço e outra o tempo. Todavia, seria tarefa hercúlea refletir sobre espaço e tempo na Recherche sem fazer um recorte específico, por isso, dentre os infindáveis recortes possíveis, propõe-se relacionar nesse artigo, dentro da própria urdidura proustiana, o espaço e o tempo à luz de determinada noção, a de tecido, expresso no símbolo da moda das roupas. Advirá dessa relação o tecido como concretude pertencente ao espaço (leitmotiv Fortuny, moda das roupas) e o tecido como trama literária, que encerra, em si, o sentido de tempo, mas que dialoga, na chave proposta, com a da moda das roupas consoante à determinada personagem (Odette). Em outras palavras, elege-se para exemplificar o elemento espaço, o leitmotiv Fortuny, e o tempo, Odette. Uma bifurcação proposital, e não menos essencial, tende a uma unificação, no sentido de que ambos - os elementos espaço e tempo - e seus respectivos arquétipos solicitados, o leitmotiv Fortuny e Odette -, participam da unidade que os consolida: a moda das roupas. A moda das roupas encerra um papel imperativo na Recherche; ela é um dos fugazes e indeléveis núcleos que, operando na subjacência, torna possível articular e, simultaneamente, aglutinar um copioso matiz de elementos, tais como os aqui implicados - o espaço e o tempo.

Portanto, acompanhando a proposta, segue-se o exame nesses termos: I. Sobre o espaço e o tempo; II. O espaço: o leitmotiv Fortuny; III. Odete como tempo; Conclusão.

\section{Sobre o espaço e o tempo}

Ponderando inicialmente acerca do espaço, a composição da matéria tecido dentro da Recherche e tomando como exemplo o tecido de Fortuny (e consequentemente o leitmotiv Fortuny), esse tecido é por excelência espaço, mensurável e objetivado, que traz em si o tempo impresso: o tempo ido, que embora irremediavelmente perdido, retorna através da reinterpretação do artista. Destarte, como um sentido em busca de significado, essa composição material se diz como sensação, pois apela essencialmente ao háptico e ao visual. Na criação dessa superfície plana e limitada, cores e formas tornam-se linguagem, signos de uma composição feita para transmudar-se, para tornar-se Outro, ou seja, a coisa como indumentária. Nesse processo essencialmente tátil e imagético, a produção de imagem é signo que pertence ao reino da exterioridade; e é através desse artifício que o aspecto visível do real se revela como signo, que pode ser desvendado. Nesse desvendamento do código estético indumentário, o visível, ao produzir certa forma ou aparência, por vezes exita alcançar o conteúdo, tal qual a essência mesma do sujeito.

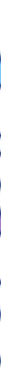


Por outro lado, ponderando sobre o tempo, faz-se mister aplicar um ponto de vista mais amplo e aprofundado. Na composição do tecido literário proustiano, dentre os distintos planos de significação que podem ser extraídos do romance, a interpretação que alude ao tempo é a via mais examinada; e isso ocorre em razão mesmo de seu objeto central, pois, embora seja possível abordar a Recherche por distintos vieses, esse romance, como indica o próprio título, é um romance concebido a partir e no tempo. A ousada e radical empreitada literária proustiana traz à tona, principalmente para a filosofia, toda a obscuridade que envolve um dos temas mais caros a essa ciência. Por isso, acolhendo a assertiva de P. Ricoeur (1995, p. 226), por exemplo, de que a obra de Proust é uma narrativa ("fábula") sobre o tempo, abre-se aqui um vasto leque de interpretações, tanto no âmbito literário como no filosófico. Evocando a ciência filosófica como matriz nessa questão temporal, pois é ela que se obstina na tentativa de apreender o conceito de tempo, temos, grosso modo, que este transita entre uma qualificação, tal qual um elemento funcional e mediador, até seu acolhimento como fundamentação do próprio ser. llustrando de modo genérico essa afirmação, e tomando um receptor estético munido de um olhar filosófico sobre o conjunto da obra proustiana, tem-se que tanto pode-se interpretá-la como uma narrativa literária aproximada do tempo kantiano - pois o escritor tem o tempo como condição a priori da sensibilidade que constrói a experiência sempre incorporada ao espaço -, como igualmente interpretá-la pós-kantianamente, ou seja, tendo o tempo como uma estrutura da consciência individual que, ao dirigir-se ao mundo, descobre-se como um universo particularizado e subjetivado pela própria condição temporal inerente aos indivíduos. Naturalmente, no rico tecido literário proustiano, outras e inúmeras leituras são possíveis no intervalo entre esses dois regimes de interpretação - entre o, digamos, infinitamente grande e o infinitamente pequeno -, e essa infinita possibilidade interpretativa traz à baila outra complexidade desse tecido: a prodigiosa e factual unidade da obra proustiana. Vinculada à questão temporal, e em função mesmo de sua (des)construção ou (des)continuidade temporal, que desdobra sucessivos eus - a voz da narrativa autoral, a do herói, a do narrador, ou seja, o "eu é um outro", lembrando Rimbaud - dentro do romance (e que conduz ao descentrado, ao acrônico, ao fragmentado), a questão da enigmática unidade se faz presente, mormente por que a provocadora obra de Proust, escapando das ortodoxas definições dos gêneros literários, inventa sua própria unidade na mesma medida em que inaugura a literatura como linguagem. E está ali - nas milhares de página da Recherche, construída entre ensaios e fragmentos, entre autobiografia e anonimato, entre novela e romance - uma obra minuciosamente planejada, tecida a partir da visão, ou do estilo do autor (PROUST, 1995b/ RTP IV) e, embora o estilo esteja longe de ser um conceito puro, porque "é uma noção complexa, rica, ambígua, múltipla" (COMPAGNON, 2001, p.173), é ele que expõe a totalidade e que torna perceptível a unidade. Conjugando, então, tempo, unidade e estilo, e contextualizando-os na "coisa como indumentária", ou seja, inter-relacionando-os no domínio da moda das roupas, encontramos no tecido proustiano uma personagem que, por meio de seu código indumentário, traz à tona o tempo; essa personagem é Odette.

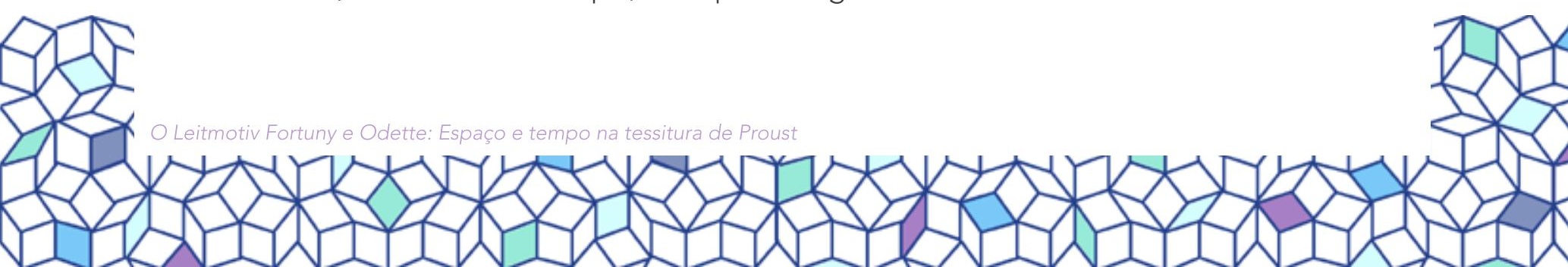




\section{O espaço: o leitmotiv Fortuny}

É notório que a moda das roupas participa fortemente da Recherche e muitas personagens comprovam a afirmação - só para citar algumas personagens, $M$. de Charlus é conhecido como La Couturière (RTP III, p.713); Oriane de Guermantes detinha a toilette mais invejada de Paris; a superlativa Odette, envolta em seus atavios, expunha em sua toilette o "conjunto fino e espiritual de uma civilização". Todavia, pensar o leitmotiv Fortuny é pensar acerca de uma cuidadosa e detalhada construção; é no leitmotiv Fortuny, "sucessivamente sensual, poético e doloroso", que Proust redimensionará o registro das roupas no romance e as (re)orientará para além da representação social. O motivo (ou o tema) é desenvolvido a partir da personagem Albertine (a amada do herói) e na elaboração de sua urdidura estão Balzac, a pintura de Carpaccio, as cidades de Balbec e Veneza, e principalmente as roupas de Fortuny - único artista real que, em plena atividade no período da feitura do romance, é imortalizado por Proust na Recherche. Assim, penetrar no tema Fortuny é fazer um percurso e examinar os elementos que o compõe.

\section{BALZAC}

Sendo as roupas parte da representação social, Proust nomeia a comunicação que ocorre através do ato voluntário de vestir-se como uma linguagem muda (1995a/ RTP III). Todavia, como toda a linguagem, a linguagem das roupas também é sistematizada, e por isso mesmo pode ser aprendida e incorporada, haja vista que ela é dotada de seus próprios ritos, códigos e símbolos - por tal aprendizagem passará Albertine em Balbec, quando tornada discípula de Elstir, como se verá mais à frente.

Por outro lado, essa linguagem pertence quase que exclusivamente ao universo feminino, que amiúde veste suas roupas como parte da estratégia de sedução, por isso, tais como armas, as roupas no universo feminino são instrumentos de guerra que atuam para despertar o interesse do olhar masculino, e nessa particular aplicação das roupas, uma "entidade" inspirou sobremaneira Proust; foi ela a princesa Diane de Cadignan, de Balzac.

A princesa Diane de Cadignan, personagem central do romance de Balzac, Os segredos da princesa de Cadignan, parece ter sido uma obsessão proustiana; além de ter participação considerável na Recherche, este "ente" é presença constante nos escritos de juventude ${ }^{2}$ de Proust. Na seleta Pastiches et Mélanges o escritor afirma, "a toilette de Mme de Cadignan é uma charmosa invenção de Balzac, pois dá uma ideia da arte de Mme de Cadignan; ela nos faz conhecer a impressão que esta quer produzir sobre d'Arthez e em alguns de seus "secretos"" (PROUST, 1971, p.136). Esse apego de Proust pela personagem-princesa sugere-nos que, para ele, essa criação balzaquiana não se reduz a uma figura dramática, ela é antes um ente sublime e instigante que tem nas roupas seu melhor meio de expressão: as roupas são parte do ardil exclusivamente feminino, e Diane de Cadignan sabe bem como portá-las e manipulá-las. Por conseguinte, pode-se afirmar que a princesa de Cadignan é a eleita por Proust como a personificação da beleza prosperada pela toilette, e seu grande porta-voz na Recherche será $M$. de Charlus.

Cf.: PROUST, Marcel. Écrits mondains. Éd. établie et présentée par Alain Coelho. Paris: UGE, 1993

O Leitmotiv Fortuny e Odette: Espaço e tempo na tessitura de Proust

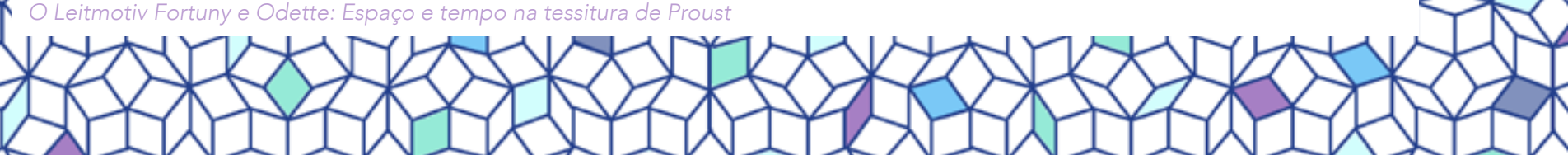


Por meio da intrigante e complexa personagem do barão de Charlus, Proust nos aproxima de Balzac, pois, dentre outros atributos, ele é um expert da obra balzaquiana.

Tal qual um poeta da mundanidade, o barão de Charlus é um autêntico aristocrata que circula pelos salões demonstrando toda a desenvoltura e soberba de sua classe. Ele, que é "um composto de conhecimentos pessoais e de fontes literárias" (De LEY, 1966, p.46), e cuja elegância é notória, conhecia como poucos os tecidos e adornos; como um perspicaz conhecedor das normas que regem a etiqueta das vestimentas (bienséance vestimentaire) apreciava aconselhar as mulheres acerca de como estar bela e ornamentada para apresentar-se em sociedade (parure). Assim, é a esta excêntrica personagem que Proust consagrou a tarefa de traduzir à Albertine - quando esta, já estando em Paris, primava, através do patrocínio do herói, por sua toilette - as lições de elegância e poder da personagem-princesa de Balzac. O barão, ou "A Costureira", mostrará a Albertine a diferença entre o vestir-se (se vêtir) e o enfeitar-se, adornar-se (s'habiller), e reconhecerá nela a semelhança com a toilette da personagem balzaquiana. Encantado com a harmoniosa toilette de Albertine em (emblemático) tom cinza, M. de Charlus diz a ela:

- Ah! [...] - eis um raio de luz, um prisma de cor. Apresento-lhe os meus sinceros cumprimentos [...] — Só as mulheres que não sabem vestir-se é que temem a cor [...] - Pode-se ser brilhante sem vulgaridade e suave sem insipidez. Aliás, você não tem os mesmos motivos que a sra. de Cadignan para querer parecer desligada da vida, pois era a ideia que ela queria inculcar a d'Arthez com o seu vestido gris (PROUST, 1995a, p. 430/ RTP III, p.442).

Pois será um vestido dessa fina estrategista na guerra da sedução, que Balzac relacionará às pinturas de Rafael ${ }^{3}$. Eis o fio primitivo, a inspiração originária que colocará em movimento o leitmotiv Fortuny: Proust, excedendo a analogia feita por Balzac, desenvolverá o tema Fortuny igualmente conectando a arte pictórica às roupas, e na criação desse processo, ou desse elã associativo, serão fomentados e desencadeados diferentes temas, e dentre esses temas, sempre em harmonia com as roupas de Fortuny, a arte pictórica, as cidades, e a memória involuntária se destacam. De tal consonância, extrai-se uma ideia de sistematização, tanto no tocante à moda das roupas como no tocante ao próprio tecido literário proustiano: ambas, moda das roupas e literatura, são linguagem, construção, arquitetura.

\section{AlberTine}

Inicialmente vale lembrar que há três ciclos de Albertine no romance: o primeiro, na cidade litorânea fictícia de Balbec, quando o herói a conhece; o segundo, remete à segunda estada do herói em Balbec, quando ele decide levá-la para morar com ele em Paris; e o derradeiro momento, quando Albertine é feita prisioneira do herói em Paris.

A Albertine Simonet que o herói conhece em Balbec é uma rapariga esportista; joga tênis, golfe, diabolo, e o mais importante, sendo ela uma moça moderna, seu meio de locomoção

BALZAC, Honoré de. La Comédie Humaine. Tome VI: Scènes de la vie parisienne II: Les Secrets de la princesse de Cadignan, Paris, Gallimard/ Pléiade, 1977, p.968. 
é a bicicleta. A erotizada "bacante da bicicleta, a musa orgíaca do golfe" (PROUST, 1984, p. 346/ RTP II, p.228), sendo uma autêntica jovem de sua época, não se acanhava, porém, em manifestar, principalmente como ciclista, nem sua modernidade e menos ainda certa ambiguidade sexual insinuada pela prática do ciclismo. Essa jeune fille sempre em perpétuo movimento, e conquanto muito feminina, é o ser de fuga (l'être de fuite) que atormentará o coração e os pensamentos do herói - especialmente em virtude, para o herói, de sua perturbadora sexualidade. Portanto, é por essa Albertine arrojada e moderna, e que se vestia com roupas esportivas - como o pólo, e o caoutchouc (impermeável), por exemplo -, por quem se apaixona o herói. Todavia, Albertine é o ser de fuga, enigmático para este; consumido pelo ciúme e pelas suspeitas sempre no tocante sua sexualidade, ele, no afã de tê-la somente para si, a torna sua prisioneira em Paris. Nesse terceiro ciclo da heroína, as roupas assumem um papel tirânico no romance, pois na tentativa de dominar e manter cativa Albertine, o herói passa a mimoseá-la com roupas e manteaux de Fortuny. E será um desses manteaux que marcará o desenlace do motivo Fortuny.

\section{Mariano Fortuny (1871-1949) e Vittore Carpaccio (c. 1465-1525/1526)}

A entrada de Fortuny no romance proustiano se dá apenas no final do segundo volume À sombra das raparigas em flor, publicado em 1919 -, determinando assim o início de uma elaboração estética assentada na moda das roupas.

A escolha de Fortuny por Proust pode ser em parte fomentada pela própria inventividade de estilista de Fortuny, que introduziu na moda feminina europeia uma modelagem inspirada nos confortáveis modelos greco-romanos e orientais: túnicas e manteaux magrebinos, togas, djelabas, caftans; todos modelos elaborados com seus tecidos exclusivos e, não raramente, urdidos com os invulgares fios metálicos. Mas o triunfo de Fortuny no campo da moda, além da criação dos tecidos inspirados em uma Veneza bizantina, orientalizada, se deu principalmente em virtude de uma criação primorosa para o vestuário feminino: o vestido Delphos, criado na primeira década de 1900. O plissado excepcional do Delphos encantou as mulheres do mundo, e lançou Fortuny como um criador de moda de vanguarda. Só a criação do Delphos bastaria para imortalizar Fortuny, entretanto, esse artista granadino, mas veneziano por escolha, foi vanguardista não apenas no campo da moda das roupas.

Por ser um artista eclético, Fortuny pode ser pensado como um artista ao molde dos humanistas, cujo anseio maior era ampliar as fronteiras do conhecimento e da criação. Além de estilista e pintor, Fortuny era um wagneriano e essa sua paixão pela música e pela estética wagnerianas o levou a trabalhar no teatro, tanto como cenógrafo, quanto como iluminador. Em sua incursão à cena dramática, Fortuny introduziu inovações significativas e uma delas vale destaque: foi ele quem inseriu em cena a luz indireta e difusa em concordância com a música; essa inovação deu uma nova dinâmica à apresentação cênica. Afora isso, ele também foi inventor e quando ainda estava morando em Paris, por volta de 1900, o Escritório Nacional de Propriedade Industrial (Office National de la Propriété Industielle) patenteou mais de vinte de suas invenções. Mas é inconteste que, a partir de 1906, quando ele se fixa em Veneza, seus interesses principais passam a ser a confecção de seus tecidos e a criação de roupas.

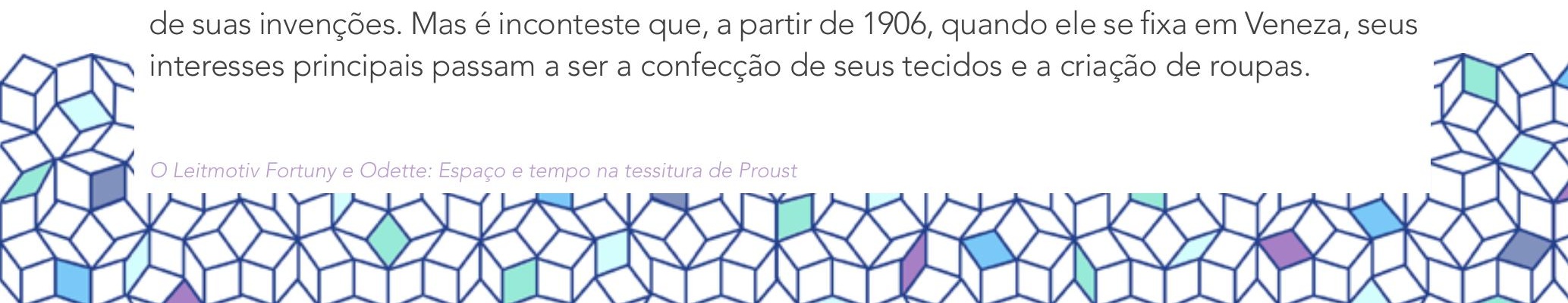


Portanto, tendo um artista como Fortuny insuflando o panorama das artes e da moda das roupas no mesmo período da composição da Recherche, não é de admirar que Proust - outras personalidades, como o poeta Gabriele D'Annunzio, por exemplo, igualmente nutriam grande admiração por Fortuny -, o tenha eleito para representar uma sutil, mas essencial, estética.

A ideia do motivo condutor estava nos planos de Proust desde ao menos 1916, como confirma a correspondência proustiana. Três cartas endereçadas a Mme de Madrazo - Maria de Madrazo, irmã de seu amigo Reynaldo Hahn, casada com Frédéric de Madrazo, filho do pintor Raymond de Madrazo, tio de Fortuny - referem-se às inspirações de Fortuny para confeccionar seus tecidos e às descrições das pinturas de Carpaccio. Na correspondência endereçada a Maria, em 17 de fevereiro desse ano, Proust lhe confidencia: o "leitmotiv Fortuny, pouco desenvolvido, mas capital, representará seu papel sucessivamente sensual, poético e doloroso" (PROUST, 1970-1993, vol. XV, p.57).

O mosaico imagético tem seu início em Balbec, e a perspicácia de Proust em lançar mão de um criador único como Fortuny (artista não-fictício) ao lado de um pintor impressionista, Elstir (fictício ${ }^{4}$ ), refinou o romance e permitiu sincronizar o passado e o presente das artes e da moda feminina através de dois criadores contemporâneos, um real e outro ficcional, ou seja, Fortuny e Elstir.

Tudo se passa no ateliê de Elstir, nas conversas entre o pintor, Albertine e o narrador. A Elstir, o pintor ficcional, caberá o papel de interlocutor que possibilitará o diálogo entre as artes pictóricas e as modas. $\bigcirc$ pintor fictício atualiza as pinturas impressionista e renascentista veneziana na discussão sobre o belo que as mulheres portam à sua época e à época de Carpaccio, Veronese e Ticiano. É nesse diálogo que Elstir afinará sua ideia de elegância à concepção balzaquiana, que consta na fisiologia Tratado da vida elegante: "é menos a simplicidade do luxo do que um luxo de simplicidade" (BALZAC, 1938, p.182), que Albertine, embora sendo aprendiz na linguagem da moda, entenderá de pronto, pois ela percebe o quanto esse "luxo de simplicidade" tem preço elevado (PROUST, 1984, p.354/ RTP II, p.239).

As imagens que nascem do colóquio sobre a moda das roupas no ateliê do artista remetem à vida na Veneza dos doges e aludem às regatas, às calli, às igrejas, à Companhia de Calza, mas principalmente às mulheres prodigamente vestidas em veludos e brocados, aos bordados e às rendas, ao ponto Veneza; é nessa conversação que Elstir introduz o nome de Fortuny:

Albertine ouvia com apaixonada atenção esses detalhes de toilette, as imagens de luxo que nos descrevia Elstir. - Oh!, como eu desejaria ver essas rendas de que me fala, é tão bonito o ponto Veneza - exclama ela - E depois eu gostaria tanto de ir a Veneza... - Talvez você possa em breve contemplar - disse-lhe Elstir - os maravilhosos tecidos que lá se usavam. Só podiam ser vistos nos quadros de pintores venezianos, ou então muito raramente nos tesouros das igrejas, e às vezes, até, aparecia algum à venda. Mas dizem que um artista de Veneza, Fortuny, redescobriu o segredo da sua fabricação e que dentro de alguns anos as mulheres poderão passear, e, sobretudo ficar

Segundo pesquisas, como referências para construção da personagem Elstir podem ser aventados Edouard Vuillard (1868-1940), ou mesmo Claude Monet (1840-1926)

O Leitmotiv Fortuny e Odette: Espaço e tempo na tessitura de Proust 
em casa, em brocados tão magníficos como os que Veneza ornava as suas patrícias, com desenhos do Oriente (PROUST, 1984, p.364-365/ RTP II, p.252)

Os pintores da Renascença veneziana lembrados fazem a ponte entre o passado e o presente do belo na moda, mas é Fortuny quem materializa o passado e o atualiza na fabricação de seus tecidos. As estampas dos tecidos de Fortuny trazem de volta uma Veneza orientalizada, bizantina, exótica e, sobretudo Carpaccio, sendo o pintor mais aludido, está intimamente arraigado nesse belo, que envolve a materialidade das roupas e a obscuridade do desejo.

Após essa aparição, Fortuny aparecerá em diversas citações no que tange à moda das roupas; em uma delas, o narrador confirmará a substancialidade que envolve a moda de Fortuny: "de todos os vestidos ou robes de chambre que usava Mme de Guermantes, os que mais pareciam obedecer a determinada intenção, ser providos de significação especial, eram os que Fortuny fez segundo antigos desenhos de Veneza" (PROUST, 1995, p.31/ RTP III, p. 543).

Sustentado por essa exclusiva significação, o herói proustiano, instrumentalizando o seu ciúme, tentará, como afirmado acima, enclausurar Albertine em Paris através das roupas, isto é, amiúde ele a mimoseará com as exclusivas criações de Fortuny na intenção de mantê-la sob seu domínio. Por vezes, porém, o herói sente que seus esforços para a agradar eram inócuos: "foi justamente na noite em que Albertine vestira pela primeira vez a robe de chambre azul e ouro de Fortuny, que, por me evocar Veneza, me fazia sentir mais ainda o que eu sacrificava por ela, que não me mostrava por isso nada agradecida" (PROUST, 1995, p.367/ RTP III, p.895). Por outro lado, a heroína, ciente da estratégia, mas em tom quase inocente, em uma noite de triunfo - quando sua toilette foi comparada à da princesa de Cadignan pelo barão de Charlus -, e envolta "em tom muito suave, róseo, azul-pálido, verdoengo, furta-cor, foi como se num céu cinzento se houvesse formado um arco-íris" (PROUST, 1995a, p.430/ RTP III, p. 442), transfere os méritos de sua encantadora toilette ao vacilante herói: "mas aqui este senhor é que tem todo o mérito - respondeu gentilmente Albertine, designando-me, pois gostava de mostrar o que devia a mim" (PROUST, 1995a, p.430/ RTP III, p. 442). O harmonioso matizado descrito no vestido de Albertine remete ao contraste do "tecido-metal pintado" (métal-étoffe teinte) que Fortuny muito utilizava e que deslumbrava o olhar. A primorosa técnica fortunyana de aplicar o ouro e a prata na trama, dava ao tecido certa dimensão sobrenatural, "quase espiritual, como foram as civilizações bizantinas, persas, árabes e islâmicas, e por fim, no tempo do Renascimento" (TUCHSCHERER, 1980, p. 22).

Infere-se dessa relação - enredada por ciúme e poder - desenvolvida pelo herói com a heroína, que, apesar de Albertine apreciar a muda linguagem dos vestidos e ter tido em Paris a oportunidade de refinar sua expressão indumentária, ela não se veste; antes, ela é vestida, ou ainda, encarcerada pelo belo da moda. Nessa temerária experiência, além de Albertine refletir o gosto do herói, ela parece igualmente convir com certo fetiche dele, pois através das escolhas estéticas dele, ela traduz e materializa (para ele) a beleza veneziana; nesse processo miasmático, é Albertine quem exprime parte significativa dos desejos mais caros e recônditos do herói: 
É preciso que um destes dias nos ocupemos de seus peignoirs de Fortuny", disse eu uma noite a Albertine [...] Enquanto esperava que aprontassem esses peignoirs, pedi alguns emprestados, às vezes mesmo só as fazendas, e experimentava-os em Albertine, envolvia-a nelas; ela passeava no meu quarto com a majestade de uma dogaresa e a graça de um manequim. Apenas o meu cativeiro em Paris se me tornava pesado à vista daqueles peignoirs que me evocavam Veneza. Sem dúvida Albertine era muito mais prisioneira do que eu (PROUST, 1995, p. 346/ RTP III, p. 872-3)

Naturalmente a estratégia de aprisionamento forjada pelo herói sucumbe, pois, mesmo tendo grande apreço pelas roupas, Albertine livra-se, embora de modo trágico, do cativeiro imposto pelo herói. Sua morte prematura será fortemente sentida por ele; todavia, certa Albertine retornará, e não por acaso, na cidade de Veneza - cidade em que, enfim, ele visitará em companhia da mãe, no desejo de afastar a tristeza que o acomete pela perda de Albertine. E é nesse retorno exclusivamente mnêmico que ocorrerá o desenlace do motivo Fortuny.

\section{O REMATE DO LEITMOTIV}

Esse contragolpe promovido pela memória involuntária une simultaneamente a roupa de Fortuny à pintura de Carpaccio, ou seja, a moda das roupas à arte; e, seguindo a dogmática construção proustiana assentada no minudente, que faz da minúcia "a base de toda a significação", a arte pictórica de Carpaccio participa do tema em dois registros distintos; um primeiro registro remete à própria eleição de Fortuny que, tomando Carpaccio como um dos mais notáveis representantes da escola renascentista veneziana, inspira-se fortemente em sua pintura para criar e produzir as estampas para seus tecidos, e principalmente os manteaux em veludo, que reproduziam motivos bizantinos. Em um segundo domínio, Carpaccio torna-se sensação, memória, dor, pois é certa pintura carpacciana que traz de volta, em um evento hipermnésico, Albertine. É neste segundo registro que se dá o epílogo do motivo Fortuny.

Como se disse, a cena se passa em Veneza; o desolado narrador, após se perder por entre as pequenas vielas venezianas, entra na Gallerie dell'Accademia de Venezia, e ao contemplar um Carpaccio (Miracolo dell'indemoniato al ponte di Rialto) recebe um golpe dado pela memória que o abate: neste quadro ele reconhece a estampa de um manteau de Fortuny que Albertine usara naquele que seria, sem desconfiarem, o último passeio do casal, antes da fuga e morte de Albertine; eis a cena, que antecede o passeio, descrita pelo narrador:

Albertine ficara no quarto, lendo, metida no peignoir de Fortuny. Perguntei-lhe se queria vir comigo a Versalhes. Ela tinha isto de encantador: estava sempre disposta a tudo, talvez por aquele hábito de antigamente ter vivido a metade do tempo em casa dos outros, e como em dois minutos se resolvera a vir para Paris, disse-me: "Posso ir assim mesmo, se não descermos do carro". Hesitou um segundo entre dois manteaux para pôr sobre o peignoir - como teria feito dois amigos diferentes que teria que levar -, decidiu-se por um azul escuro admirável [...] (PROUST, 1995, p.376/ RTP III, p.906) 
Estando em frente a pintura de Carpaccio, é a lembrança dessa noite que retorna; a exposição que segue é emblemática, pois une de uma só vez moda e arte: na contemplação de uma pintura de Carpaccio, o herói proustiano, num jogo associativo, vislumbrará na mencionada peça de roupa (manteau) confeccionada por Fortuny, Albertine, já morta, ressurgir em Veneza:

Enfim, antes de deixar o quadro, meus olhos regressaram à margem, onde formigam cenas da vida veneziana da época. Olhava o barbeiro enxugando sua navalha, o negro carregando o seu tonel, as conversas dos muçulmanos, nobres senhores venezianos em amplos brocados, em damascos, com gorros de veludo cor de cereja, quando senti, de repente, como que um leve aperto no coração. Às costas de um dos companheiros da Calza, reconhecível pelos bordados de ouro e pérolas que inscrevem em suas mangas ou coletes o emblema da risonha confraria à qual eram filiados, eu acabava de identificar o casaco que Albertine usava quando fora comigo à Versalhes em carro descoberto, na noite em que eu estava longe de pensar que apenas quinze dias me separavam do momento em que ela iria embora de minha casa. Sempre disposta a tudo, quando lhe pedira que partisse, naquele triste dia que ela deveria chamar, em sua última carta, duas vezes crepuscular, visto que a noite caía e nós falamos em nos separar, ela atirava aos ombros um casaco de Fortuny que levara consigo no dia seguinte e que, desde então, eu jamais tornara a ver em minhas lembranças. Ora, era neste quadro de Carpaccio que o genial filho de Veneza o utilizara, fora nas costas desse membro da Calza que o havia assinalado, a fim de lançá-lo sobre tantas parisienses que decerto ignoravam, como eu até agora, que o modelo existia num grupo de cavalheiros, no primeiro plano do Patriarca de Grado, numa Academia de Veneza. Eu reconhecera tudo e, tendo o esquecido casaco me devolvido, ao vê-lo, os olhos e o coração daquele que ia, naquela noite, partir para Versalhes com Albertine, fui invadido, durante alguns instantes, por um sentimento perturbador, logo dissipado, de desejo e de melancolia (PROUST, 2002, p.489-490/ RTP IV, p. 225-226)

Novamente a memória involuntária captura o narrador e uma onda de sentimentos e emoções aflora; a revivescência que traz Albertine, ou antes, o fantasma de Albertine, condena o herói a uma inevitável (re)experimentação do tempo, agora sob a "condição de ressurreição, porque um instrumento de morte" (BECKETT, 2003, p.35).

Por outro lado, ainda que Proust tenha apenas assinalado que "às costas de um dos companheiros da Calza, reconhecível pelos bordados de ouro e pérolas que inscrevem em suas mangas ou coletes o emblema da risonha confraria à qual eram filiados [...]" , Anguissola (1994) identificou no quadro de Carpaccio, no capuz de um manteau, o bordado de uma sereia com dupla cauda, símbolo de morte e ressureição, e assinalou ainda que, nas costas de um dos companheiros da Calza (em uma espécie de mochila), percebem-se escritas as palavras CON TEMPO. Tais exames especulares ampliam consideravelmente a concepção do quanto o leitmotiv Fortuny foi rigorosamente planejado; elemento algum tem uma

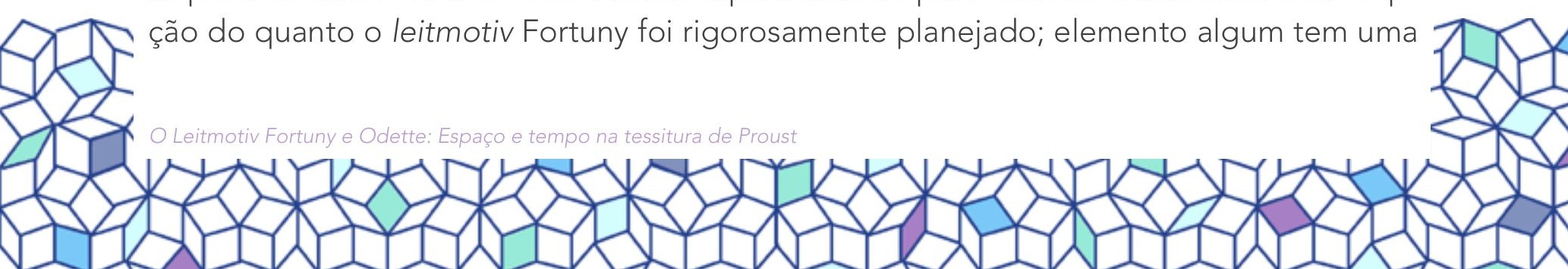


participação fortuita ou dispensável, pelo contrário, cada fio da urdidura encontra-se com outro fio do tema, que se junta a mais outro, para, ao final, vislumbrar-se a trama tecida.

Todos os diferentes fios urdidos colocam em relevância a roupa que ressurge como tempo revisitado em determinado espaço, por isso, nessa urdidura o espaço, antes mesmo do tempo, tem papel fundador.

No interior da revivescência estão os espaços: a cidade de Veneza e a cidade de Balbec, a cidade real e a cidade ficcional. Elas carregam em seu poder os elementos basilares que estruturam a estética do leitmotiv: a arquitetura, as igrejas, a memória, os desejos, os amores, os encontros e os desencontros, a agonia da perda. As cidades são signos de uma representação particular, o espaço da elaboração estética, e sobretudo Veneza, o espaço onde se materializam os tecidos de Fortuny, surge como o espaço catalizador de vida, morte e ressurreição:

Eram essas robes de chambre de Fortuny, uma das quais vira eu na sra. de Guermantes, as que Elstir, quando nos falava das vestimentas magníficas das contemporâneas de Carpaccio e Ticiano, nos anunciara para breve, renascendo suntuosas de suas cinzas, pois tudo tem que voltar, como está escrito na abóbada de São Marcos, e como o proclamam, bebendo nas urnas de mármore e de jaspe dos capitéis bizantinos, os pássaros, que significam ao mesmo tempo morte e ressurreição (PROUST,1995, p. 344/ RTP III, p. 871)

Desse modo, como espaço e imagem é Veneza que sobeja e ilumina a trama estética com as cores e as luzes de suas pinturas renascentistas recriadas nos tecidos fortunyanos; o mito Veneza, ou esse "sanatório de silêncio e de luz" (CHEVRIER, 2009, p. 80), como definiu Proust essa peculiar cidade, assume toda a dramaticidade exigida pelo leitmotiv Fortuny; suas calli, igrejas e pontes redundam em sensações e promessas. De contraparte, a fictícia Balbec insinua-se nesta estética em chave pessoal, e pode ser pensada como espaço da distensão, do relaxamento de naturezas diversas, sendo a mais evidente a sexual, pois foi na cidade litorânea, em que as moças se espalhavam pelas ruas da cidade com suas roupas esportivas, que o adolescente conheceu as delícias e os primeiros dissabores do amor. Proust escolheu Veneza como promessa de ventura e Balbec como espaço do encontro; e a Fortuny pertenceu, por direito, a especial tarefa de representar a materialidade, a beleza tangível e memoriável de um passado:

À maneira dos cenários de Sert, de Bakst e de Benoist [sic], que nessa ocasião evocavam nos bailados russos as épocas de arte mais apreciadas - com o auxílio de obras impregnadas de seu espírito e todavia originais -, esses peignoirs de Fortuny, fielmente antigos mas fortemente originais, faziam aparecer como um cenário, com maior força de evocação mesmo do que um cenário, pois o cenário ficava por imaginar, a Veneza toda atravancada de Oriente onde teriam sido usados, e da qual eram, mais do que uma relíquia no relicário de São Marcos evocadora do sol e dos turbantes de em torno, a cor fragmentada, misteriosa e complementar. Tudo desse tempo havia perecido, mas tudo renascia, evocado para ligá-los uns aos outros pelo esplendor da paisagem e o

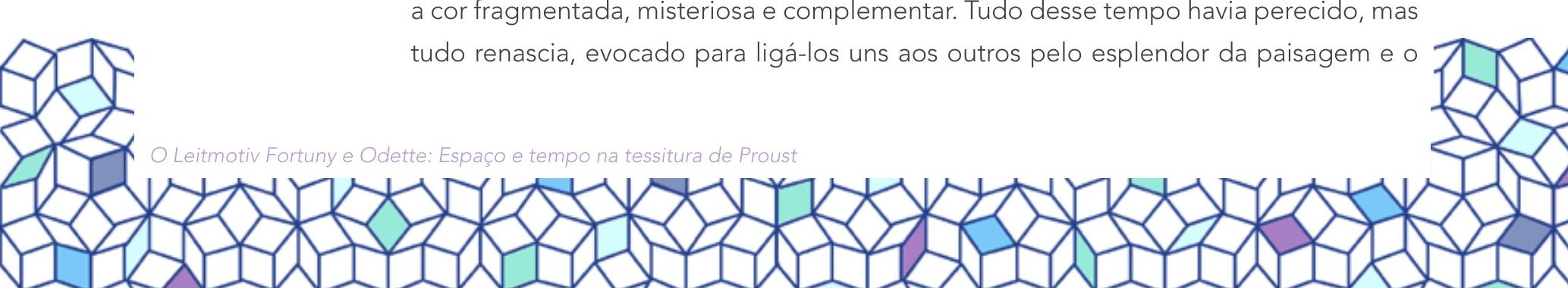


pulular da vida, pelo surto parcelar e sobrevivente dos tecidos das dogaresas (PROUST, 1995, p. 344-345/ RTP III, p. 871-872)

Os tecidos de Fortuny estampam o espaço onírico da cidade anfíbia que, com seus becos e labirintos de pedra, parece convidar a todos a um jogo de decifração, no qual o mistério da beleza dessa cidade é passível de ser desvelado. Assim, a arte de Fortuny, "o genial filho de Veneza", ao ser imortalizada por Proust, converte-se, junto com a cidade, em espaço decodificado dos afetos.

\section{Odette como tempo}

Primeiramente: Odette não participa do leitmotiv Fortuny e, pelo que se sabe, nem seria uma apreciadora de seus modelos - assim como de roupas esportivas, como o suéter (sweater), muito em moda na virada do século XIX para o século XX; sabe-se, porém, que ela é "uma fervorosa de Raudnitz" (PROUST, 1984, p.139/ RTPI, p.588). Entretanto, um exame dessa personagem é incontornável, pois Odette é o símbolo de uma época e sua participação no tecido proustiano, especialmente no tocante a um exame da moda das roupas, avulta-se na medida em que ela carrega em sua representação indumentária a característica subjetivada de ser tempo. Em outros termos, principalmente na chave da moda das roupas, Odette é a mais rica personagem desenvolvida por Proust, porquanto ela é a personagem que, com excelência, sabe manipular, através de suas vestimentas, sua própria identidade e alteridade, assim, "se há uma dimensão pela qual a toilette de Odette acede a um grau verdadeiramente superior, este é o do Tempo" (MILOVANOVIC, 2005, p.62). Odette é a personagem da perenidade pois, além de ter presença ativa em toda a caminhada do romance até ao final dele, contrariamente a outras personagens que também se mantém vivas no final da obra, Odette não caduca (como M. de Charlus) e nem se torna uma mera figura obsoleta (como a duquesa de Guermantes). Na matinée dos Guermantes (Le Bal des têtes), o narrador parece nos confidenciar que, apesar da ação do tempo ter sido cruel com a maioria dos convivas, apenas Odette parece possuir a faculdade de escapar de suas ofensas, pois permanece "tão formosa ainda"; ironicamente, porém, antes de seu inevitável fenecimento, esta conservação será análoga a uma "rosa esterilizada" (PROUST, 1995b, p.216/ RTP IV, p. 528).

\section{1. $\bigcirc$ período que antecede Odette}

A atuação de Odette no romance é um fiel retrato de certa casta de mulheres - as afamadas demi-mondaines, cocottes parvenues, femmes entretenues, cortesãs, grandes horizontais -, e cuja importância é vital para a moda das roupas na sociedade parisiense de então.

Segundo pesquisas ${ }^{5}$, Odette teria nascido no início do Segundo Império (1852-70), isto é, por volta de 1850; portanto, Odette crescerá no período áureo da burguesia francesa, mas só participará efetivamente da sociedade no fim, ou após o Segundo Império, seu apogeu será, então, na Belle Époque.

5 Cf.: Françoise Leriche afirma que, após indicações dos cadernos de esboço de Proust, Odette teria nascido em 1852, in: Dictionnaire Marcel Proust. BOUILLAGUET, Annick; ROGERS, Brian G. Paris: Honoré Champion, 2004, p. 703 [verbete: Odette]

O Leitmotiv Fortuny e Odette: Espaço e tempo na tessitura de Prous

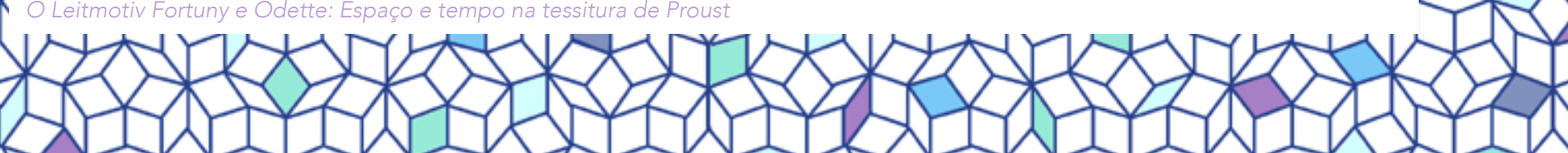


O Segundo Império enceta o fastígio das cortesãs; mas é ainda o período dos grandes magazines, dos salões e do início oficial da alta-costura. Por isso, especialmente para a moda das roupas esse é um período importante, pois marca a entrada em cena de uma nova categoria de profissionais no mercado, os costureiros.

Em 1855 nasce a alta costura na figura de Charles F. Worth, que estabeleceu os cânones que regem a moda até os dias de hoje (desfile para apresentação dos modelos; lançamentos para cada nova estação; exclusividade, etc.). Worth instituiu, junto com a imperatriz Éugénie, a saia-balão como o expressivo modelo da época - a introdução de uma armação de metal sob a crinolina (tecido resistente colocado em cima da armação) foi ideia da imperatriz Eugénie e rapidamente seguida por toda sua corte; por se tratar de moda, e como toda moda é imitação que tende ao exagero, a saia gradativamente alcançará diâmetros de inimagináveis três metros. A maison de $M$. Worth atendia as mais renomadas mulheres de Paris: "a princesa de Metternich, a princesa Mathilde, a condessa di Castiglione, Mme Octave Feuillet, Sarah Bernhardt; Worth aceita ainda vestir Cora Pearl, la Païva, e algumas outras atrizes de renome" (LANGLADE, 1997, p.23), logo, além de clientes abastadas da alta burguesia e da nobreza do Segundo Império, as atrizes e as demi-mondaines, que nessa lista estão praticamente indistintas, igualmente terão o privilégio de ser vestidas pelo prestigioso criador.

A moda das roupas viverá a partir de então seu auge como produto, pois além do advento da alta-costura, é nesse período que surge a máquina de costura como um utensílio acessível e, assim, a prodigalidade técnica e a criatividade humana unem-se em favor do real estabelecimento da moda das roupas como um forte setor do mercado de consumo, fomentado mormente pela expansão burguesa. Adotando um viés sociológico, tradicionalmente (por medo da proletarização) é a classe média que tenta a todo custo elevar-se, por isso ela invariavelmente imita as classes superiores; a prática da imitação, sendo uma universalidade - afinal, "ela é, em si mesma, o fato essencial da vida em sociedade" (TAR$\mathrm{DE}, 1895$, p.181) -, torna-se cenário da moda, agora facilitado pela máquina de costura e pela farta disponibilidade de tecidos e atavios, um procedimento não só corriqueiro, mas fundamental: é ela que fomenta o mercado.

Assim, no ágil ritmo brilhante e capitalista do Segundo Império, é por meio dessa peculiar inserção social ensejada pela moda, que o "espetáculo da vida moderna" (BAUDELAIRE, 1976, p. 495) se torna possível para um grande número de pessoas, mas principalmente para as mulheres. Na esteira desse caráter exibicionista da vida na sociedade de mercado, as roupas estão intimamente relacionadas à urbanidade e a uma prática civilizada recém instituída como chic: a prática do ver e ser visto. Todos querem ver e ser vistos nos teatros, restaurantes, cafés e bulevares; o olhar atento é o aferidor social: observa-se, antes de qualquer preceito, a sapiência para adequar-se às ocasiões - é o comme il faut -, e evocando novamente Balzac, como a roupa é o mais "enérgico de todos os símbolos" (BALZAC, 1938, p.163), é ela o poderoso signo que terá a função de revelar a distinção ou cupidez - de qualquer ordem - daquele ou daquela que a traja. 
Nesse ponto, uma complexa fronteira entre o ser e o parecer sugere expressar certas aspirações dessa sociedade. Explicitando o argumento, a sociedade parisiense, a partir do Segundo Império, assim como a moda, se verá em meio a constantes mudanças, principalmente por conta da flexibilização social - uma realidade desde a Revolução (1879), quando as ambicionadas paridades sociais são tomadas como um escopo da sociedade francesa. Desse modo, tomando a perspectiva da moda das roupas como o axial condutor, que tem como princípio que a moda só pode desenvolver-se numa "sociedade individualista, rica e móvel" (NATTA, 1996, p. 9), na metade do século, essa sociedade - a sociedade do parvenu, do homem que se faz por si mesmo, o self-made-man - vê medrar em seu seio belas e inúmeras cocottes parvenues, e são essas conhecidas demi-mondaines, que, sem um nome ou uma tradição para manter-se fiéis, tornam-se objetos de experimentação da incipiente categoria de profissionais masculinos, os costureiros, os quais já eram glamorizados no século XIX - os costureiros eram identificados, já no século XIX, como estilistas.

As cocottes penetram o cenário da moda e tornam-se os seres particulares, os sujeitos de experimentação dos estilistas. Essa impetuosa clientela feminina é cobaia dos criadores de moda e, de certo ângulo - o de ser uma criatura de um criador -, essa exótica clientela participa intimamente da sexualidade do criador. Todavia, nessa aventura excitante e arriscada, não serão apenas as cortesãs que serão sujeitos de experimentação; também as atrizes, e um pouco menos as cantoras, serão eleitas como criaturas dos criadores, e isso ocorre porque em meados do século XIX, ser uma atriz (ou cantora) era uma profissão ambígua, e muito suspeita, para a mulher. Talvez como um consolo por serem tão arrojadas, serão essas mulheres que ditarão a moda parisiense.

Por outro lado, essas belas mulheres sabem que os trajes e os acessórios, incluindose aí as joias que acompanham uma bela parure, são poderosos instrumentos de guerra nessa sociedade em que elas são vitrines, por isso portar um vestido exclusivo, assinado é fomentar a possibilidade de manifestar-se literalmente como imagem que nutre distintas significações, mas dentre elas, a mais forte é a que alude ao poder.

Barthes situa a sociedade do Segundo Império como inebriada e enlouquecida com a autoridade suprema das joias, e como ilustração cita Naná, de Zola, como o fruto de uma sociedade duplamente arruinada pela destruição e devoração, e conclui: "a mulher é simultaneamente devoradora (mangeuse) de homens e de diamantes" (BARTHES, 2002, p.1091). Contudo, vale lembrar: essas elegantes e onerosas mulheres realizam um papel bem específico nessa sociedade: celebrar, de modo dissimuladamente velado, o triunfo dos ricos e poderosos que podem mantê-las:

Dispendiosas, as mulheres elegantes são para exaltar a glória de seus protetores, muito rico e poderosos o suficiente para fazer das caçadoras de fortunas, seus diamantes. Objetos de posse e exibição, eles se excluem de ostentar sobre si os símbolos demasiado evidentes da ociosidade e da vida dispendiosa, mas não são elas os emblemas do sucesso, do índice exterior de riqueza? (PERROT, 1981, p.184) 


\section{A construç̃̃o de OdetTe}

Odette é fruto dessa época e parece ter feito um caminho comum a muitas mulheres do período: uma obscura Odette de Crecy é uma atriz banal que começa a ganhar a vida com a prostituição e torna-se uma meretriz elegante e uma conhecida cocotte do demi-monde. Casa-se com o respeitado Charles Swann, de quem tem uma filha, e torna-se Odette Swann; após a morte deste, novamente casa-se, com o conde de Forcheville, e torna-se Odette de Forcheville. Este é o percurso oficial de Odette na narrativa, todavia há ainda outras duas aparições insinuantes da personagem: a Dame en Rose e a Miss Sacripant; sem saber que se tratava da mesma pessoa, o narrador só ulteriormente teve a identidade das enigmáticas e dissimuladas mulheres reveladas: ambas eram Odette.

Destas várias Odettes, uma será abundantemente descrita, a Odette Swann. A personagem é apresentada pelo narrador por meio de suas roupas e dos adornos; é esta a Odette que se vê através do olhar de Swann, e depois dos olhos do próprio narrador.

O início do contato com Odette e sua família se dá, quando o narrador, ainda jovem, conhece Gilberte, filha de Odette e Charles Swann, que era amigo da família do narrador.

Inicialmente o narrador encontrará com Mme Swann no Bois de Bologne; em Mme Swann au Bois o narrador descreve ao longo de muitas páginas as diversas toilettes de Odette. Começa aqui seu fascínio por ela. A característica mais marcante das descrições de Odette pelo narrador é o tom poético-pictórico. Seu olhar sobre esta mulher é de um diletante; ele a vê como uma obra de arte que embeleza o espaço que a abriga, seja passeando pela alameda das Acácias ou pela alameda da Rainha Margarida; ela, com seu apuro, eleva a beleza do próprio lugar; sua harmoniosa toilette integra-se à paisagem do Bois de Bologne tornando-o mais belo (MARANTES, 2011).

Depois o narrador passará a frequentar a casa dos Swann e, se primeiramente as visitas do narrador tinham o intento de encontrar Gilberte, este fito se atenua na medida em que ele, tornando-se íntimo dos Swann, se norteará em direção ao legendário e elegante Charles Swann de sua infância, e depois, naturalmente, em direção a sua fascinante mulher Odette, de quem ele se tornará o "cortesão assíduo" (COUDERT, 1998, p.65).

É nesse ciclo do romance que o narrador se deixará inebriar pelo poder dessa sedutora mulher, que, favorecida pela moda do período, se vestia tão diafanamente como uma Vênus botticelliana. Por isso, no que diz respeito as roupas, o narrador observa que os quimonos japoneses usados por Odette em seu boudoir em épocas passadas para receber, por exemplo, um Swann apaixonado, já não estavam mais em moda; o que vigora na moda da Belle Époque para receber na intimidade do lar são os tea gowns, moda oriunda da Inglaterra e fortemente propugnada pelos pré-rafaelitas, que trazia a novidade de liberar, ao menos em casa, os corpos femininos - os modelos conhecidos como tea gown, deshabillés, robes de chambre, peignoirs, négligés eram vestidos de uso doméstico e confortáveis, e por isso mesmo dispensavam o uso do espartilho, ou do corpete. Assim, quando em visita na casa dos Swann, o jovem narrador não apenas apreciava a indumentária de Odette, mas, podia ainda, e sem dificuldade, apreciar os contornos de seu corpo sob sedas e musselinas vaporosas dos robes de chambre e peignoirs Watteau (PROUST, 1984, p. 152/ RTP I, p.605).

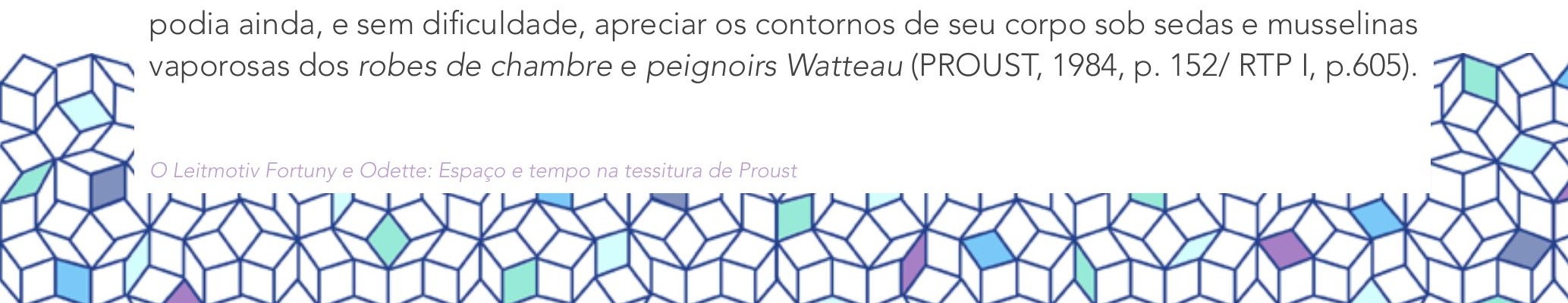


Especificando um pouco a moda à la Watteau, convém assinalar que, por trazerem na parte das costas uma grande prega que descia dos ombros até o chão, formando uma cauda - esse modelo de vestido é amiúde encontrado na pintura Jean-Antoine Watteau (18641721), por isso essa designação -, os vestidos, no final do século XIX, podiam, então, não ser somente apreciados de frente, mas de perfil e de costas, e tal mudança de perspectiva açulada pela moda parece sugerir simultaneamente uma mudança do olhar e, igualmente uma mudança da própria mulher na sociedade, que paulatinamente ia granjeando seu próprio espaço.

Assim, adotando as aconchegantes e vaporosas vestimentas, que em geral eram confeccionadas em tons esmaecidos e delicados (remetendo ao tom da pele), Odette parecia acariciar a própria pele; toda sua languidez e suavidade incorporam-se aos robes. $\bigcirc$ narrador tinha suas preferências: o peignoir de crepe da China era "mais elegante que todos os vestidos". Sua reverência a Mme Swann de peignoir era visível:

Ela também ia preparar-se, embora eu protestasse que nenhum vestido de passeio se igualaria ao maravilhoso peignoir de crepe da China ou de seda, rosa fanado, cereja, rosa Tiepolo, branco, malva, verde, vermelho, amarelo liso ou com desenhos, com que a Sra. Swann havia almoçado e que ia tirar. Quando eu the afirmava que devia sair assim, ela ria, por zombaria de minha ignorância ou prazer por meu cumprimento. Desculpava-se de possuir tantos peignoirs porque achava que só com eles é que se sentia à vontade (PROUST, 1984, p.94/ RTP I, p.531)

Na mesma medida em que Odette é observada, ela é exaltada e desejada. A exibição indumentária da cocotte provocou no romance conexões estéticas, principalmente promovidas por seus apreciadores, Swann e narrador; nas representações estético-pictóricas emuladas, Odette sempre conserva uma subliminar perenidade, como propõe F. Dugast-Portes:

Odette é magnificada através das referências picturais que ela suscita: ela é a filha de Jéthro pintada na parede da Sistina, assemelhada a um Botticelli; seu vestido de quarto é "rosa Tiepolo", etc. [...] Tudo é inicialmente inserido através do imaginário cultural de Swann, e em seguida o narrador segue o trabalho de transfiguração; desse modo, Odette, lembrando as obras de arte de épocas distintas, sintetiza as belezas de épocas diferentes [...] (DUGAST-PORTES, 1989, p.55)

A sempre desejada Odette tem estilo e é por essa via (nebulosa) que a personagem se opõe a outra personagem notável na Recherche: a duquesa de Guermantes.

\section{A moda de Oriane e a moda para Odette}

Seguindo a tradição do século XVIII, os salões no século XIX são igualmente dirigidos por mulheres. No romance proustiano, muito da vida que se perde, se perde nos salões e, grosso modo, há na Recherche dois tipos de salões em oposição, os da aristocracia e os da

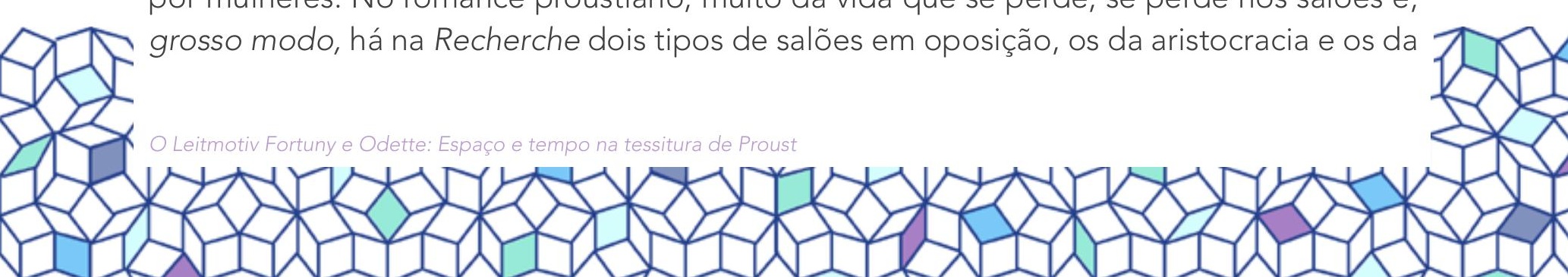


burguesia. O salão da burguesia, que Odette frequenta, é representado por Mme Verdurin, uma dreyfusista, que tem entre seus frequentadores intelectuais e artistas de vanguarda. $\bigcirc$ salão da aristocracia é representado pelos salões da rive gauche, no faubourg Saint-Germain e, o salão mais disputado, para o qual todos querem ser convidados, é o da duquesa Oriane de Guermantes; seu salão é o endereço da mais perfeita aristocracia.

Oriane, sendo uma autêntica representante de uma França campesina aristocrática, faz questão de conservar tanto uma pronunciação particularizada, formada por um vocabulário puro e antigo, quanto certos ritos protocolares como signos de sua casta. Desse modo, os Guermantes mantêm, em grau mais ou menos flexível, estruturas cerimoniosas praticadas pela remota etiqueta palaciana como sinal do conservadorismo, e isso os diferencia tanto das demais camadas sociais quanto de nobres que não os interessam. Consequentemente, o salão de Oriane, por orientar-se pela tradição monárquica, pouco recebia artistas ou intelectuais; apenas a fina flor da aristocracia francesa e europeia tinham o privilégio de privar e participar do "espírito de Guermantes", que De Ley traduz como "um dos encantos do francês de antanho" (De LEY, 1966, p.42).

Odette, embora tendo se casado com Swann, que era grande amigo da duquesa, foi permanentemente repelida por Oriane, que fazia questão de mantê-la à distância de seu círculo. Entretanto, esta distância de caráter social estende-se e aprofunda-se no que tange à moda das roupas; é na representação indumentária que ocorre a grande cisão entre as personagens.

Aparentemente Oriane e Odette, no que se refere à representação indumentária, visam e atingem a um mesmo fim: são exemplares do belo aprimorado através das roupas, isto é, sendo a roupa a parte mais visível na representação e exibição social, tanto a duquesa quanto Odette, cada uma em seu registro, souberam intensificar plenamente sua beleza por meio da moda. Contudo, como se tentará expor, examinando mais de perto as duas personagens, nota-se que entre elas instala-se não uma mera distância de grau, mas de natureza, como se tentará demonstrar.

Pensemos na duquesa. Não é menor o papel de Oriane no tocante à moda das roupas, todavia Proust não reservou a duquesa algo além de uma bela imagem, pois é isso que as descrições de sua toilette oferecem. Assim ocorre por que a duquesa é a femme du monde, a rainha da sociedade; ela sabe como ser elegante e defende soberanamente seu papel de uma das mulheres mais bem vestidas de Paris. Mas não é tarefa fácil aproximar-se da duquesa que, aliás, prefere ser admirada a requisitada: como há sempre um espaço aurático imposto e interposto entre ela e os demais, é esta distância que permite contemplar sua parure sempre tão bem cuidada. Sua afamada elegância, contrariamente à de Odette, aposta na simplicidade; este é o elemento fundamental na arte de vestir-se de Oriane, é assim que ela suplanta suas rivais: "em vez das maravilhosas e suaves plumas que desciam da cabeça ao pescoço da princesa, em vez da sua rede e conchas e pérolas, a duquesa não tinha nos cabelos senão uma simples aigrette [...]" (PROUST, 1996, p. 48/ RTP II, p.353). Simplicidade é a característica fundamental na parure de Oriane; ela, contrastando com seus pares femininos, prefere a sobriedade aos extravagantes adornos e, esta estratégia, além de diferenciá-la das demais aristocratas, ainda "tinha o poder de dar às outras a aparência

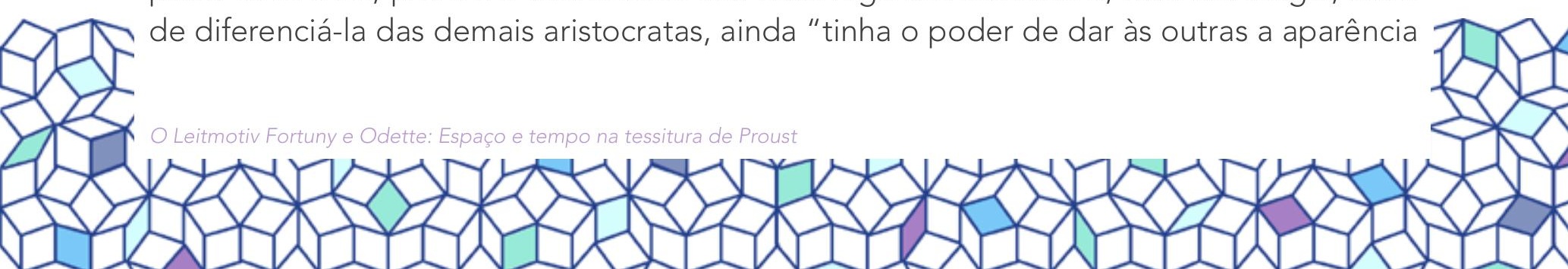


de deslocadas" (BIDOU-ZACHARIASEN, 1997, p. 41). Adotando tal postura imperiosa, a duquesa, mesmo sem o saber, segue os preceitos balzaquianos do luxo de simplicidade, que como se observou, demanda um alto investimento. O narrador, admirando a elegância de Oriane de Guermantes, que assiduamente vestia Fortuny, pede-lhe conselhos sobre moda na intenção de melhor orientar sua Albertine na arte da linguagem das roupas. Essa conversa entre o narrador e a duquesa é significativa, pois nela pode-se divisar o alcance estético da duquesa, que se pauta, como prerrogativa de sua classe, no luxo e na exclusividade dos modelos. Neste fragmento o narrador assinala o mau odor de um vestido que lembra uma asa de borboleta - uma criação de Fortuny, que usava claras de ovos podres vindos da China como fixador dos pigmentos; a fixação na roupa descrita não deve ter sido adequada, considerando o intenso odor desagradável exalado:

Tenho muito gosto em the emprestar tudo o que você quiser, mas olhe, se você mandar fazer coisas de Callot, de Doucet, de Paquin por costureirinhas, nunca será a mesma coisa". "Mas eu não pretendo ir a nenhuma costureirinha, sei muito bem que será outra coisa, mas me interessaria compreender porque será outra coisa". "Ora, você bem sabe que eu não sei explicar nada, sou uma boba, falo como uma camponesa. É uma questão de jeito, de feitio; quantos às peles, posso ao menos dar-lhe uma recomendação para meu fornecedor, o que lhe evitará ser roubado. Mas, mesmo assim, custar-Ihe-á uns oito ou nove mil francos". "E aquela robe de chambre que cheira tão mal, que a senhora estava com ela outro dia, uma escura, macia, salpicada, listrada de ouro como uma asa de borboleta?" "Ah! Aquela é de Fortuny. Sua amiguinha pode muito bem usar aquilo em casa. Tenho muitas, vou mostrar-lhe, posso mesmo dar-lhe algumas, se lhe faço prazer com isso (PROUST, 1995, p.39-40/ RTP III, p.552)

Essa é Oriane, a aristocrata que sabe acerca dos imprescindíveis dados axiológicos que tornam a roupa uma peça elegante e enobrecedora, e nessa passagem fica evidente o quanto ela preza uma peça de autor: ela admite usar um robe de chambre malcheiroso simplesmente por ser esta uma peça de um grande artista (Fortuny), ou seja, a duquesa, embora dissimule, sabe cabalmente o valor que tem uma roupa assinada. Infere-se, então, que a moda das roupas para a duquesa assume a ordinária fugacidade das modas, pois para ela o papel das roupas se restringe à representatividade social, que é sempre oscilante e pautada na frivolidade. Mas, mormente, Oriane, expressando sua casta, encena o espírito da alta moda: ela é a encarnação do faubourg Saint-Germain, e talvez por isso mesmo, suas roupas, ou ainda sua parure, são tão invejadas; contudo, elas nada refletem além de uma bela imagem.

Por outro lado, refletindo sobre Odette, é notório que a demi-mondaine tem estilo, mesmo não seguindo uma moda; é por isso que sua pródiga apresentação indumentária ultrapassa as fronteiras da mera imagem. Entretanto, estilo é um termo muito vasto, e numa tentativa de aproximar Odette e estilo, pode-se afirmar que, em seu modo pessoal, individualizado de trajar-se, Odette legitima-se; ou em outros termos, é seu modo particular de vestir-se que lhe dá identidade, pois seus vestidos e arranjos se harmonizam de tal forma

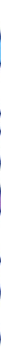


com ela, que parecem ser uma extensão de seu corpo. Eis o detalhe que determina a distância que separa Oriane de Odette: enquanto para a duquesa as roupas são elementos de representação no teatro mundano, as roupas são para Odette elementos constitutivos de sua natureza, elas participam de sua essência e existência; uma usa a moda como meio, e outra como fim, respectivamente. Portanto, não há entre elas, no tocante à moda das roupas, uma separação de grau, o que possibilitaria uma categorização; antes, há um isolamento, uma ruptura, pois a diferença é de natureza, e como se exporá na sequência, segundo a interpretação aqui dada no domínio das roupas, é em virtude dessa peculiaridade imanente à Odette, que a personagem converte-se em tempo.

\section{OdetTE: suas Roupas, sua IDENTIDADE}

Odette inventou genuinamente um estilo, mas não somente no tocante à moda das roupas, mas seguindo o ponto de vista de Gilda de Mello e Souza no tocante à condição das mulheres no período, Odette construiu um estilo de existência: "a mulher desenvolveu ao infinito as artes relacionadas com sua pessoa criando um estilo de existência - talvez a sua única contribuição original à cultura masculina" (SOUZA, 1987, p.106). Tal estilo de existência deslindado por sua toilette é referência, é ele que a individualiza, e as imagens identificadoras de Odette, em permanente diálogo com o tempo, são a personificação apoteótica da mulher do fim do século erotizada.

Assim, ela, cultivando o mito da mulher-esfinge - instigado, entre outros, por Gustave Moreau (1826-1898) -, e sem ser excessiva, mas apelando sempre para os detalhes inúteis, serve-se de diversos tipos de botões, rendas, fitas, laços e acessórios para compor seu conjunto indumentário:

Ao mesmo tempo a complicação de adornos sem utilidade prática e sem aparente razão de ser acrescentava àqueles trajes tão vivos um matiz desinteressado, pensativo, secreto, muito de acordo com a melancolia que ainda conservava a Sra. Swann [...] certa fila de botõezinhos de cetim que não abotoavam nada e não podiam desabotoar-se, uma trancinha que pretendia agradar com a minúcia e discrição de uma delicada lembrança (PROUST, 1984, p.155/ RTP I, p.609)

Odette zela em seu vestuário pelos vestígios de um tempo constantemente efêmero e, tal qual uma caligrafia individualizada das lembranças passadas, ela escreve a construção de si mesma numa relação que alterna identidade e alteridade, sem com isso desvencilharse de sua essência. E se as roupas de Odette são como uma parte efetiva de sua identidade, perguntar pela identidade da demi-mondaine é pensá-la através das cores e flores, que estando conectadas, compõem ambas as pródigas imagens da personagem.

A cor é fundamental na moda das roupas e é perceptível o percurso cromático de Odette no romance; seu movimento pictural, sempre em concordância com as roupas, revela a contingência das alterações: ela passa do inicialmente óbvio-feminino tom rosa da dame en rose ao branco moralizador da dame en blanc em Tansonville, quando casada com Swann,

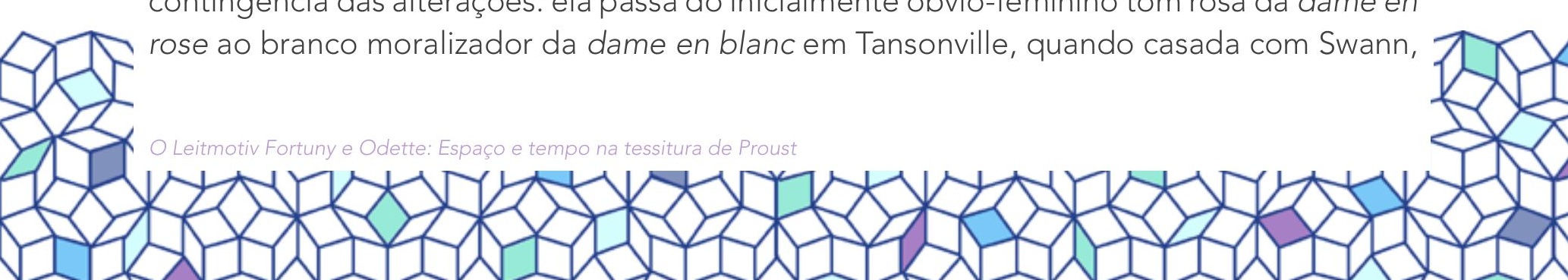


para atingir, enfim, a notabilidade de uma majestade, porém, sem perder "a provocação da cocotte" com os erotizados tons rosa-violeta da malva em Paris, que podem ser pensados como "sua nudez, seu impudor" (COUDERT, 1998, p.69).

E assim como Odette, "flor e planta não têm vontade consciente. Não têm pudor e expõem sua genitália" (BECKETT, 2003, p.96). No tocante às flores, as referências mais notórias são os lilases, os crisântemos e principalmente as catleias, as orquídeas que foram moda na segunda metade do século XIX em Paris, e que se tornaram símbolo, na Recherche, do amor de Swann e Odette, pois "fazer amor" era "fazer catleias".

Por associá-la o narrador à flora, ao belo da natureza, e muito embora exibindo uma composição indumentária repleta de detalhes e artifícios, Odette parece fazer jus à abominação baudelairiana em Mon cœur mis à nu, de que "a mulher é natural, ou seja, abominável" (BAUDELAIRE, 1975, p.677), pois todas as estratégias e artifícios de sua composição indumentária lhes são naturais; unificam-se nela. Odette é flor que se integra, se metamorfoseia, se abre, como na descrição do narrador da chegada de Odette ao Bois de Bologne: "de súbito, pela areia da alameda, tardia, vagarosa e luxuriante como a flor mais bela e que só se abrisse ao meio-dia, aparecia a Sra. Swann, desabrochando em redor de si uma toilette sempre diferente" (PROUST, 1984, p.167/ RTP I, p.625).

Concomitante a esta Odette feita de imagem está a personagem que evidencia o paradoxo da moda das roupas, pois com ela não há moda passada, mas uma harmônica comunhão entre o tempo, como duração - tempo bergsoniano, absolutamente fluido e contínuo -, e o tempo cíclico das roupas:

A Sra. Swann quis e soube guardar vestígios de algumas dessas modas entre as novas que vieram substituí-las [...] costumava encontrar a Sra. Swann em elegante traje caseiro: a saia, de belo tom sombrio, vermelho-escuro ou alaranjado, essas cores que pareciam ter particular significado, porque já não estavam em moda, era obliquamente atravessada por uma ampla faixa com calados de renda negra, que trazia à memória os volantes de antigamente [...] naquela tarde fria de primavera em que fomos ao Jardin d'Acclimatation [...] a Sra. Swann ia mais ou menos entreabrindo, quando o passeio the dava calor, a gola de sua jaqueta, de modo que assomava a gola denteada da blusa como a entrevista lapela de um casaco que não existia, igual àqueles que usara anos antes e que Ihe agradava que tivessem as bordas picotadas; e a gravata escocesa - pois continuara fiel ao escocês, mas suavizando tanto os tons (o vermelho convertido em rosa e o azul em lilás), que quase se confundiam com os tafetás furta-cor que eram a última novidade - ela a trazia atada de tal maneira por debaixo do queixo, sem que se pudesse ver de onde saía, que a gente logo recordava uma daquelas fitas de chapéu já desusadas. Por pouco que soubesse arranjar-se para "durar" assim algum tempo mais, os jovens diriam, procurando explicar suas toilettes: "A Sra. Swann é toda uma época, não é verdade?" Do mesmo modo que num bom estilo onde se superpõem formas distintas e que se enraíza numa oculta tradição, do modo de vestir da Sra. Swann, essas incertas recordações de casacos ou de laços, e às vezes uma tendência, logo refreada, para o casaco 
de marinheiros, e até uma alusão vaga e remota ao pega-rapaz, faziam palpitar sob as formas concretas a vaga parecença com outras formas mais antigas, que não se podia dizer estivessem verdadeiramente realizadas pela modista ou a chapeleira, mas que se apoderavam da memória e rodeavam a Sra. Swann de certa nobreza, ou porque aqueles atavios, por sua própria inutilidade, parecessem atender a finalidades superiores ao utilitário, ou pelo vestígio conservado dos anos transatos, ou ainda por uma espécie de individualidade indumentária característica daquela mulher e que emprestava a seus mais diferentes vestidos um ar de família. Via-se perfeitamente que não se vestia tão-só para comodidade ou adorno do corpo; ia envolta nos seus atavios como no aparato fino e espiritual de uma civilização (PROUST, 1984, p. 154-155/ RTP I, p. 608-609)

Odette, sob um olhar berkeleyano, parece crer que ser é ser percebida (esse est percipi), pois os detalhes de uma moda passada inclusos em sua composição indumentária, além de harmônicos a sua essência, são provocações que excitam o olhar e aguçam o interesse do outro. E talvez seja este o ponto alto de sua exibição que, até involuntariamente, almeja mostrarse como a expressão de seu espírito, de sua substancialidade. Isso ocorre de tal modo que o ser de Odette experimenta "um pouco do tempo em estado puro", pois conjugando em si passado e presente, ela abstrai-se desse mundo e apreende sua própria atemporalidade.

Assim, é sobretudo o tempo que se faz sentir nas descrições das vestimentas de Odette, e apoiado nessa aprioridade, Proust desenvolve certa metafísica da sedução, que tem como princípio os encantos de uma beleza perene - contrariando a fugacidade que rege a moda, a perenidade será exclusividade de Odette, que sobretudo como Odette Swann funda-se como "museu da ornamentação, mulher eterna; Mme Swann testemunha o tempo sem ser alterada por ele [...]" (COUDERT, 1998, p.67). De tal perspectiva, a personagem pode ser pensada como a encarnação do belo feminino proustiano, do feminino que resiste e conserva-se; muito embora a morte seja certa, o processo de envelhecimento pode ser postergado, por isso, na matinée dos Guermantes, o tempo, não obstante indistintamente implacável e cruel com todos, poupará Odette, que perpetuará sua beleza "à custa de carmins e tintas ruivas".

Todavia, o fenecimento de Odette, ainda que não seja manifesto na obra, é, assim como o de todos os seres vivos, incontornável:

Tão formosa ainda, ganhara a mais - o que nunca possuíra - uma infinita simpatia; porque, ela que enganara Swann e todo o mundo, era agora enganada pelo universo inteiro; e tão fraca estava que nem ousava, tendo-se invertido os papéis, defender-se dos homens. Dentro em breve nem da morte se defenderia (PROUST, 1996b, p.217/ RTP IV, p.530)

Portanto, no rico tecido literário proustiano, Odette é a personagem que, mesmo não podendo vencer a única certeza de todos os seres vivos - seres de linearidade evolutiva, que caminham para sua inevitável degeneração -, transita no e com o tempo. Distinta por seu código indumentário, é ele que consolida a identidade individual da personagem, que devém

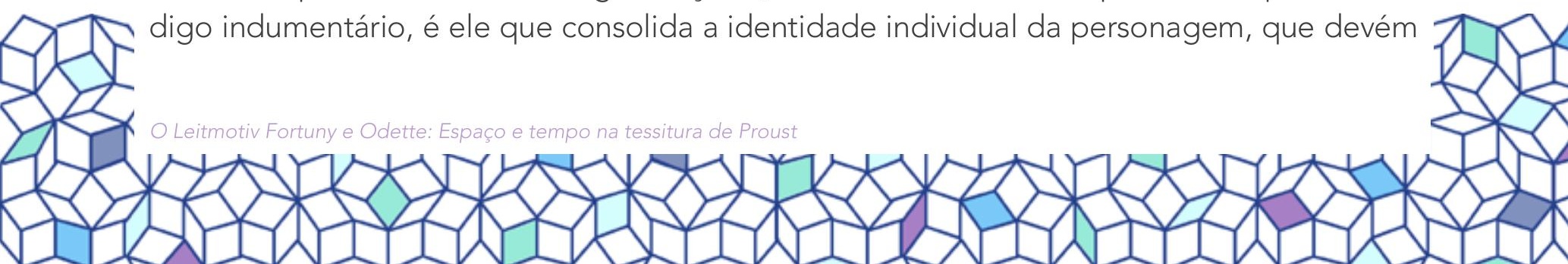


interioridade em exterioridade, e nesse processo transmutativo surge não só a autonomia estética, mas o conteúdo essencialmente espiritual e atemporal que subjaz na personagem.

\section{Conclusão}

Proust soube com inigualável perspicácia entremear a Recherche com as mais distintas (e elevadas, no sentido das artes elencadas), expressões humanas. Todavia, é na instância do que há de mais efêmero, a moda das roupas, que se revela a fina contextura de seu romance. Generoso, Proust compôs uma obra em que a moda das roupas torna-se uma minudência estética relevante, consequente; é a moda das roupas que avança e revela simultaneamente o irredutível e o maleável: o espaço como a via material, objetiva, referente a um belo tangível (o tecido tramado por fios; as vestimentas); e o tempo como a via complexa e subjetiva, que nessa trama da moda substancializa-se numa personagem (Odette), e que, concomitantemente, é o próprio núcleo duro, fértil do tecido literário proustiano que, em virtude mesmo de sua complexa costura entrelaçada ao tempo, pode ser pensado como aporético, autotélico, intransitivo, autorreferencial.

\section{Referências}

ANGUISSOLA, Alberto Beretta "Pélerinages proustiens à Venise", in: BMP, n 44, 1994, p.42-58.

BALZAC, Honoré de. Fuvres Diverses (1830-1835) (vol. II). Paris: L. Conard, 1938.

BARTHES, Roland. Fuvres Complètes (Tome I, 1942-1961). Paris: Seuil, 2002.

BAUDELAIRE, Charles. Fuvres Complètes (I et II). Texte établi, présenté et annoté par Claude Pichois, avec la collaboration de Jean Ziegler. Paris: Gallimard/ Pléiade, 1975-1976.

BECKETT, Samuel. Proust. Trad. A. Nestrovski. São Paulo: Cosac \& Naify, 2003.

BIDOU-ZACHARIASEN, Catherine. Proust Sociologue: de la maison aristocratique au salon bourgeois. Paris: Descartes \& Cies, 1997.

COMPAGNON, Antoine. Proust entre deux siècles. Paris: Éditions du Seuil, 1989.

. O demônio da teoria: literatura e senso comum. Trad. C. P. B. Mourão; C. F. Santiago. Belo Horizonte: Ed. UFMG, 2001.

CHEVRIER, Jean-François. Proust et la Photographie. La Résurrection de Venise. Paris: L'Arachnéen, 2009.

COUDERT, Raymonde. Proust au féminin. Paris: Grasset/ Le Monde, 1998.

De LEY, Herbert. Marcel Proust et le duc de Saint-Simon. Urbana and London: University of Illinois Press, 1966.

DICTIONNAIRE MARCEL PROUST. Publié sous la direction d'Annick BOUILLAGUET et Brian G. ROGERS. Paris: Honoré Champion, 2004.

DUGAST-PORTES, Francine. Le Goût selon Odette (p. 43-59). In: Marcel Proust: Geschmack und Neigung. Volker Kapp (Hrsg.). Tübingen: Stauffenburg-verlag, 1989.

LANGLADE, Jacques de. Oscar Wilde, Stéphane Mallarmé: Noblesse de la Robe. Paris: Les Belles Lettres, 1997. 
MARANTES, Bernardete Oliveira. $O$ Vestido de Proust: uma construção na trama das correspondências. 2011. Tese (Doutorado em Filosofia) - FFLCH/ USP, São Paulo, 2011. [Disponível em: http://www.teses.usp.br/teses/disponiveis/8/8133/tde-11042012-160413/] (Acesso em: 2015-08-01).

NATTA, Marie-Christine. La Mode. Paris: Anthropos, 1996.

MILOVANOVIC, Momcilo. Les figures du livre. Essai sur la coïncidence des arts dans À la recherche du temps perdu. Paris: Honoré Champion/ Recherches Proustiennes 5, 2005.

PERROT, Philippe. Les Dessus et les Dessous de la bourgeoisie. Une Histoire du vêtement au XIXeme siècle. Paris: Fayard, 1981.

POULET, Georges. O espaço proustiano. Trad. A. L. B. Martins Costa. Rio de Janeiro: Imago/ Biblioteca Pierre Menard, 1992.

PROUST, Marcel. À la recherche du temps perdu (4 vols.) Éd. établie et présentée par J.-Y. Tadié. Paris: Gallimard/ Pléiade, 1987-1989.

Contre Sainte-Beuve, precedé de Pastiches et mélanges et suivi de Essais et articles. Éd. établie par Pierre Clarac avec la collaboration d'Yves Sandre. Paris: Gallimard/ Pléiade, 1971.

. Correspondance de Marcel Proust. Éd. établie par Philip Kolb (21 vol.). Paris: Plon, 1970-1993.

Écrits mondains. Éd. établie et présentée par Alain Coelho. Paris: UGE, 1993.

À sombra das raparigas em flor. Trad. M. Quintana. São Paulo: Abril Cultural (sob licença da Ed. Globo, Porto Alegre), 1984.

A prisioneira. Trad. M. Bandeira; L. S. de Alencar. São Paulo: Globo, 1995 (12ed.)

Sodoma e Gomorra. Trad. M. Quintana. São Paulo: Globo, 1995a (13ed.).

O tempo redescoberto. Trad. L. M. Pereira. São Paulo: Globo, 1995b (12ed.).

O caminho de Guermantes. Trad. M. Quintana. São Paulo: Globo, 1996 (11ed.).

Em busca do tempo perdido (Vol. III). Trad. F. Py. Rio de Janeiro: Ediouro, 2002.

RICOEUR, Paul. Tempo e Narrativa (Tomo II). Trad. M. Appenzeller. Campinas: Papirus, 1995.

SOUZA, Gilda de Mello e. O espírito das roupas. A moda no século dezenove. São Paulo: Companhia das Letras, 1987.

TARDE, Gabriel. Les Lois de I'Imitation. Paris: Alcan, 1895 (2e éd.).

TUCHSCHERER, Jean-Michel. La création d'étoffes, (p.19-23); in: Catalogue de l'exposition Mariano Fortuny Venise (19 avril au 13 juillet 1980). Musée Historique de Tissus de Lyon. Commissaire de l'exposition: Guillermo de Osma, Lyon, 1980.

Recebido em: 18/08/2015 Aceito em: 10/11/2015

Referência eletrônica: MARANTES, Bernardete Oliveira. O Leitmotiv Fortuny e Odette: Espaço e tempo na tessitura de Proust. Criação \& Crítica, n. 15, p. 102-125, dez. 2015.

Disponível em: <http://revistas.usp.br/criacaoecritica>. Acesso em: dd mmm. aaaa. 